\title{
Microbial Population Structure In Circulating Cooling Water System Makeup By Municipal Reclaimed Water
}

\author{
HUANHUAN HUANG ${ }^{1}$, PING XU ${ }^{1 *}$, JIE WANG $^{2}$, CHANGZHENG WANG $^{1}$ \\ ${ }^{1}$ National Experimental Teaching Demonstration Center of Water Environment, Beijing University of Civil Engineering \\ and Architecture, Beijing 100044, China \\ ${ }^{2}$ Beijing Datang Carera Investment Co, Beijing 100083, China
}

\begin{abstract}
The municipal reclaimed water, which often reused in circulating cooling water system, can effectively alleviate the urban water crisis. However, the reclaimed water contains a large number of microorganisms while the water environment in circulating cooling water system allows the microorganisms to further increase. Therefore, circulating cooling water system faces slime, corrosion and other microbial problems. In this work, the microbial population structure of circulating cooling water makeup by municipal reclaimed water was investigated by using modern molecular biology DNA technology. Our results demonstrated that at the level of family, there were 17 kinds of suspended microorganisms in municipal reclaimed water, in which the dominant strain belonged to Proteobacteria, Betaproteobacteria, Methylophilales, Methylophilaceae. For the circulating cooling water without chemical agents, 13 kinds of suspended bacterias and 36 kinds of immobilized bacteria were detected, in which the dominant strain respectively was Comamonadaceae and Pseudomonadaceae which belonging to Proteobacteria Betaproteobacteria. After adding chemical agents, the number of suspended bacteria increased to 26 kinds and the distribution of bacteria species was even more. And the dominant strain become Staphylococcaceae, which belonged to Firmicutes, Bacilli, Bacillales, the reason for this was the sharply increase of TOC and TP after adding scale and corrosion inhibitors. Corrosion of instrumentation and pipe network systems caused by microorganisms is particularly complicated in circulating cooling water systems and even in whole reclaimed water utilization systems. The corrosion mechanism and corrosion process caused by different microorganisms are different. Therefore, it is very important to explore the composition of microorganisms in reclaimed water to study the corrosion of microorganisms. Based on the study of microbial population structure in municipal reclaimed water, this paper explores the microbial population structure and dominant species in the water in response to the specific situation in which reclaimed water is reused in the circulating cooling water system. At the same time, it also provides some research suggestions for the future research on the corrosion caused by microorganisms in the reuse of recycled water.
\end{abstract}

Keywords: Reclaimed water, Circulating cooling water supply, microorganism, microbial abundance.

\section{Introduction}

Currently, China is a big country of thermal power in the world. However, the shortage of water resources has become the one of the biggest bottleneck in the development of energy industry [1]. In thermal power industry, the circulating cooling water consumption accounts for about $50 \%$ to $80 \%$, and the water quality demand is relatively low. Therefore, utilizing of municipal reclaimed water is considered one of the most effective ways to alleviate water resource scarcity [1-2]. Although the microbial growth in circulating cooling water is limited by the nutrient, even if the limited breeding is enough to influence the circulating cooling water system. Ray et al [3] suggested that the zones where contain enough organic carbon and other nutrients can support the growth of biofilms consisting mainly of bacteria and bacterial with symbiotic relationships. The municipal reclaimed water contains

\footnotetext{
*email:pxu.126@gmail.com; xuping@bucea.edu.cn
} 
nutrients such as organic matter, nitrogen and phosphorus needed for the growth and reproduction of microorganisms. Moreover, the long-distance transportation also allows micro-organisms to adapt to the water environment for further growth and reproduction. Therefore, the appropriate water temperature environment, adequate dissolved oxygen and the stimulation of the concentration effect in the circulating cooling water system may cause more serious slime, corrosion and other microbial problems [4-5].

Bacterial communities have attracted considerable attention because of these microbial problems [6-7]. In order to eliminate the security risks caused by the reuse of municipal reclaimed water on power plant and reduce the economic loss, it is urgent to carry out the research on the microbial characteristics and control technology of the circulating cooling water system replenished by the municipal reclaimed water. The bacterial communities have been investigated in drinking water distribution pipes due to water quality security [8-9]. However, few studies focused on bacterial communities in circulating cooling water system replenished by municipal reclaimed water in spite of the fact that the reclaimed water has been widely utilized.

Since the 1970s, the understanding of the microbial population structure has been mainly depended on the traditional isolation and culture methods [10-11]. These methods have the disadvantages of low distinguishability, incomplete understanding and selectivity on the diversity of microbial population structure [12]. Modern molecular biology techniques, especially molecular biology based on $16 \mathrm{~S} \mathrm{r}$ DNA, has been widely used in the study of microbial population structure because of their ability to accurately and intuitively reveal the microbial diversity [13-16]. Therefore, we applied the modern molecular biology DNA technology to study the microbial diversity in circulating cooling water system replenished by municipal reclaimed water based on the analysis of a large number of conventional water quality and microbiological indicators. In addition, we also revealed the microbial structure characteristics and evolution of microbial population by the laboratory research and field trials.

\section{Materials and methods}

\subsection{Water Sample Collection}

The municipal reclaimed water was collected from a municipal reclaimed water replenishment pipeline in a thermal power plant of Beijing, the image of static reactor is shown in Figure 1a. The addition of water treatment agents will affect the water quality, which in turn affects the microbial population structure, so the circulating cooling water with and without water treatment agents were both studied. The circulating cooling water replenished by the municipal reclaimed water without water treatment agents was collected from a dynamic simulation device installed in the power plant. The water supply pipe of the dynamic simulation device was drowning directly from the plant's municipal reclaimed water replenishment pipeline. The image of dynamic simulation device is shown in Figure $1 \mathrm{~b}$, the circulation flow is $0-2000 \mathrm{~L} / \mathrm{h}$, the inlet water temperature of the simulated heat exchanger is $20-40{ }^{\circ} \mathrm{C}$ and the cooling temperature of the cooling tower is $8-12{ }^{\circ} \mathrm{C}$. The circulating cooling water with water treatment agents was taken from the circulating cooling water system in power plant.

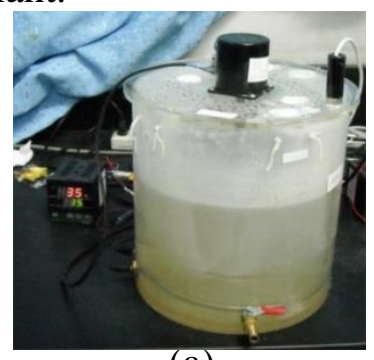

(a)

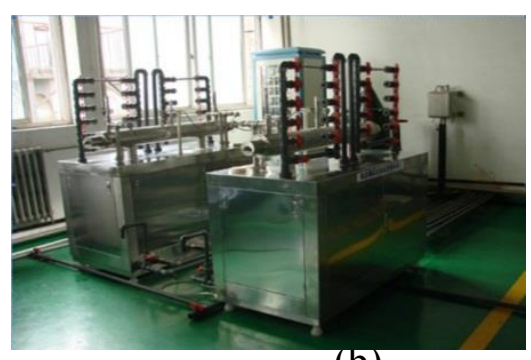

(b)

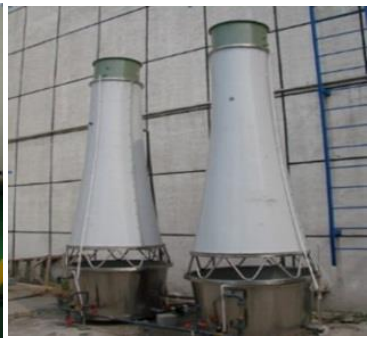

Figure 1. Photo of device. a) Static reactor. b) Photoes of dynamic simulation device 


\subsection{Experimental method}

The studied samples included the microorganisms in municipal reclaimed water, the suspended and immobilized microorganisms in circulating cooling water makeup by municipal reclaimed water without water treatment agents, the suspended microorganisms in circulating cooling water makeup by municipal reclaimed water with water treatment agents, respectively. The comparison on microbial population structure of the above four samples was carried out by the modern molecular biology DNA technology.

\subsubsection{Extraction and detection of DNA}

The collected samples were extracted with the DP320 genome extraction kit, the extraction method was carried out according to the kit instructions. To detect the concentration and purity of DNA, we took $2 \mu \mathrm{L}$ of DNA sample and added dilute water to $1 \mathrm{~mL}$, the absorbance value of the mixed liquid was detected at $260 \mathrm{~nm}$ and $280 \mathrm{~nm}$ on a Nano Drop 1000 Spectrophotometer. The concentration value of DNA was calculated according to formula $\mathrm{C}=\mathrm{V} \times \mathrm{OD}_{260} \times 50 / 1000$, where $\mathrm{C}$ is the DNA concentration $(\mathrm{ng} / \mu \mathrm{L}), \mathrm{V}$ is the sample amount $(\mu \mathrm{L})$, then the ratio of the absorbance at $260 \mathrm{~nm}$ and $280 \mathrm{~nm}$ was calculated, $\mathrm{OD}_{260} / \mathrm{OD}_{280}$ should be between 1.7 and 1.9 , otherwise the DNA should be reextracted.

\subsubsection{PCR amplification of 16 Sr DNA.}

The Bacteria universal primers used in the experiment was B27F (5'-AGA GTT TGA TCC TGG CTC AG-3') and U1492R (5'-GGT TAC CTT GTT ACG ACT T-3'). The PCR amplification was performed with the purified DNA as template. The PCR amplification system was shown in Tabale 1.

Table 1. PCR Amplification System

\begin{tabular}{|c|c|}
\hline Medicine name & Dosage \\
\hline 10×PCR Buffer & $5 \mu \mathrm{L}$ \\
\hline dNTPs(10mM each) & $1 \mu \mathrm{L}$ \\
\hline Template(DNA) & $2 \mu \mathrm{L}$ \\
\hline primer27F $(10 \mu \mathrm{M})$ & $2 \mu \mathrm{L}$ \\
\hline Taq DNA polymerase $(2 \mathrm{U} / \mu \mathrm{l})$ & $1 \mu \mathrm{L}$ \\
\hline primer1492R $(10 \mu \mathrm{M})$ & $2 \mu \mathrm{L}$ \\
\hline $\mathrm{ddH}_{2} \mathrm{O}$ & $37 \mu \mathrm{L}$ \\
\hline Total & $50 \mu \mathrm{L}$ \\
\hline
\end{tabular}

PCR amplification conditions: $94^{\circ} \mathrm{C}$ pre-denaturation $10 \mathrm{~min} ; 94{ }^{\circ} \mathrm{C}$ denaturation $1 \mathrm{~min}, 53{ }^{\circ} \mathrm{C}$ annealing $30 \mathrm{~s}, 72{ }^{\circ} \mathrm{C}$ extension $1.5 \mathrm{~min}$, cycle 35 times; stores at $72{ }^{\circ} \mathrm{C}$ for $10 \mathrm{~min}$, at last $4{ }^{\circ} \mathrm{C}$ keep warm.

\subsubsection{TA Cloning and Sequencing}

The purified PCR target bands were ligated into pMD18-T carrier, and then it was transformed into Escherichia coli competent cells DH5 $\alpha$ and coated on LB plates containing X-gal and IPTG. To obtain the result of bi-directional sequencing, we picked the monoclonal and sent it to the sequencing company. 


\subsubsection{OTU Analysis}

After the sequencing sequence was jointed, the sequence before $50 \mathrm{bp}$ of the $5^{\prime}$ end and the sequence from the $50 \mathrm{bp}$ to the end of the 3' end was removed, then the OTU clustering and species abundance analysis was carried out: We used the cd-hit-est tool in the cd-hit software package to select the similarity threshold of 0.97 , then the $16 \mathrm{~s}$ rDNA sequence obtained by sequencing was clustered to obtain the OTUs (operational taxonomic units). In each OTUs, the sequence with the longest fragment length was selected as the representative sequence of the OTUs. To identify the species attribution of the representative sequence of each OTUs, we used the classifier based on a Bayesian statistical model provided by the RDP database, and set the assessment threshold of the bootstrap approach as 0.8 (similarity of $99 \%$ ). At last, the table of species abundance was obtained by counting the sequence number in each OTUs.

\subsubsection{Shannon and Simpson Index}

The Shannon and Simpson index can respectively reflected the diversity and uniformity of bacterial population structure. Therefore, the Shannon and Simpson indexes of the three water samples were also calculated as the following formula:

$$
\begin{aligned}
& \text { Shannon: } H^{\prime}=-\sum P_{i} \times\left(\operatorname{In} P_{i}\right) \\
& \text { Simpson: Simpson }=1-\sum P_{i 2}
\end{aligned}
$$

$\mathrm{Pi}-\mathrm{The}$ number proportion of the $\mathrm{Ni}$ individual in the total population, $\mathrm{Pi}=\mathrm{Ni} / \mathrm{N}$.

\section{Results and discussions}

3.1. Analysis of Water Quality in Municipal Reclaimed Water and Recirculating Cooling Water

Water quality is a decisive factor of microbial population structure in water. Therefore, we studied 10 kinds of water quality indicators of municipal reclaimed water and recirculating cooling water.

\begin{tabular}{|c|c|c|c|}
\hline Index & Unit & Municipal reclaimed water & Circulating cooling water \\
\hline temperature & ${ }^{\circ} \mathrm{C}$ & 23.9 & 23.8 \\
\hline TOC & $\mathrm{mg} / \mathrm{L}$ & 4.55 & 13.82 \\
\hline $\mathrm{TP}$ & $\mathrm{mg} / \mathrm{L}$ & 0.273 & 0.697 \\
\hline Soluble TP & $\mathrm{mg} / \mathrm{L}$ & 0.195 & 0.490 \\
\hline TN & $\mathrm{mg} / \mathrm{L}$ & 35.098 & 36.726 \\
\hline Ammonia & $\mathrm{mg} / \mathrm{L}$ & 1.867 & 1.278 \\
\hline Nitrate nitrogen & $\mathrm{mg} / \mathrm{L}$ & 9.219 & 16.199 \\
\hline Nitrite nitrogen & $\mathrm{mg} / \mathrm{L}$ & 0.342 & 0.864 \\
\hline $\mathrm{SO}_{4}^{2-}$ & $\mathrm{mg} / \mathrm{L}$ & 122.254 & 175.873 \\
\hline $\mathrm{Cl}^{-}$ & $\mathrm{mg} / \mathrm{L}$ & 118.178 & 369.353 \\
\hline
\end{tabular}

Table 2. Water Quality of Municipal Reclaimed Water and Recirculating Cooling Water

The quality of reclaimed water can meet the requirements of water indicators, which was very important for the reuse of reclaimed water (Table 2). However, after entering the circulating cooling water system, the content of nutrients such as carbon, nitrogen and phosphorus was higher, the TOC, TP, TN increased 3.04 times, 2.55 times, 1.05 times, respectively, which may result in the increase of the microbial number. In addition, a higher chloride and sulfate contents also lead to an increased risk of metal corrosion in circulating cooling water system. 


\subsection{Comparison of Microbial Population Structure}

Comparison of municipal reclaimed water and circulating cooling water. The comparison results of microbial population structure in municipal reclaimed water and circulating cooling water at the level of class was shown in Figure 2.
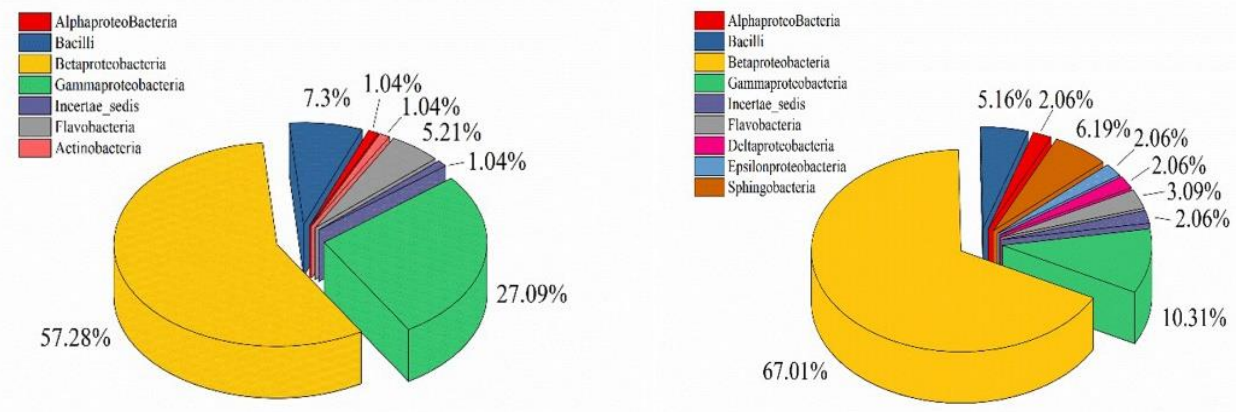

Municipal reclaimed water

Circulating cooling water

Figure 2. Microbial population structure at the level of class

As was shown in Figure 2, the microbial diversity in the two samples was almost the same, the largest number were both Betaproteobacteria, and then were the Gammaproteobacteria.

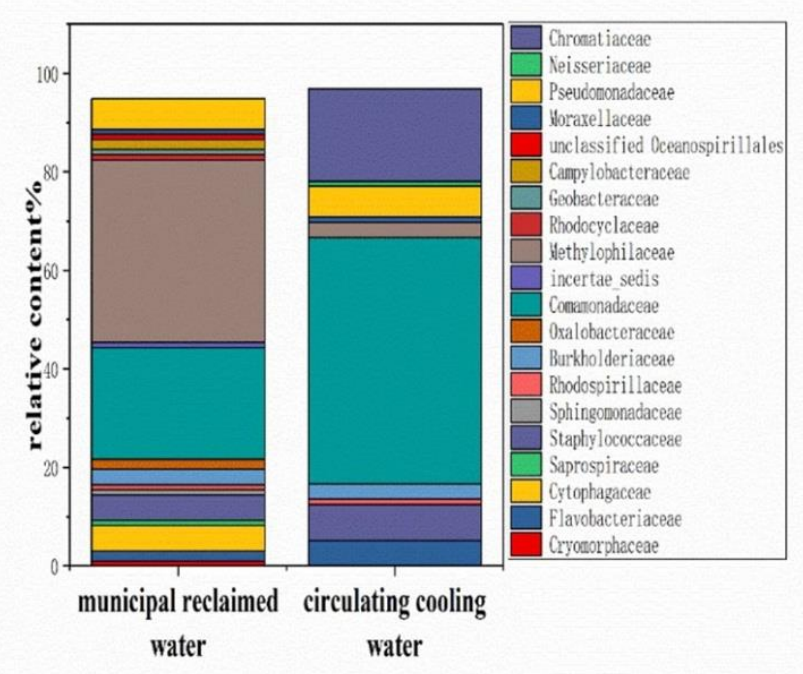

Figure 3. Microbial population structure at the level of family

At the level of family, there were 17 kinds of microorganisms in municipal reclaimed water and 13 kinds in circulating cooling water, the color's type of the two samples was similar, but the corresponding bar's height of each color was different, it indicated the bacterial species was similar but different in relative content. 


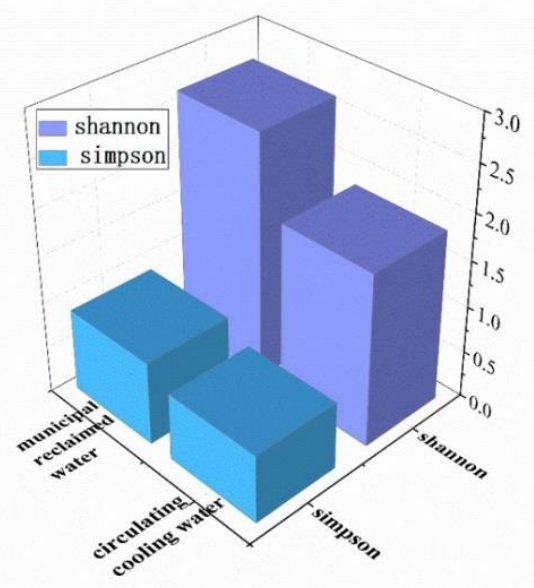

Figure 4. Compasion of shanoon and simpson index

Compared with municipal reclaimed water, the Shanoon and Simpson index increased 1.44 times and $23.2 \%$, respectively, in circulating cooling water. Therefore, microorganisms in circulating cooling water had a higher diversity and the species were more evenly distributed.

Table 3. The dominant microorganisms in reclaimed water and circulating cooling water

\begin{tabular}{|c|c|c|}
\hline Number & Municipal reclaimed water & $\begin{array}{c}\text { Circulating cooling water without } \\
\text { water treatment agents }\end{array}$ \\
\hline 1 & $\begin{array}{c}\text { Proteobacteria } \\
\text { Betaproteobacteria } \\
\text { Methylophilales } \\
\text { Methylophilaceae } \\
37.12 \%\end{array}$ & $\begin{array}{c}\text { Proteobacteria } \\
\text { Betaproteobacteria } \\
\text { Burkholderiales } \\
\text { Comamonadaceae } \\
47.9 \%\end{array}$ \\
\hline 2 & $\begin{array}{c}\text { Proteobacteria } \\
\text { Betaproteobacteria } \\
\text { Burkholderiales } \\
\text { Comamonadaceae } \\
16.5 \% \\
\end{array}$ & $\begin{array}{c}\text { Proteobacteria } \\
\text { Gammaproteobacteria } \\
\text { Chromatiales } \\
\text { Chromatiaceae } \\
\text { Rheinheimera } \\
18.8 \% \\
\end{array}$ \\
\hline 3 & $\begin{array}{c}\text { Proteobacteria } \\
\text { Gammaproteobacteria } \\
\text { Pseudomonadales } \\
\text { Pseudomonadaceae } \\
\text { Pseudomonas } \\
6.2 \% \\
\end{array}$ & $\begin{array}{c}\text { Firmicutes } \\
\text { Bacilli } \\
\text { Bacillales } \\
\text { Staphylococcaceae } \\
\text { Staphylococcus } \\
7.3 \% \\
\end{array}$ \\
\hline
\end{tabular}

It can be seen from Table 3 that the highest abundance of microorganisms in the two samples were both from Betaproteobacteria, which was Methylophilaceae in municipal reclaimed water accounting for $37.12 \%$, while was Comamonadaceae accounting for $47.9 \%$ in circulating cooling water.

Using the method of molecular weight classification, the reclaimed water and circulating cooling water were graded into five water samples respectively with molecular weights of $>100 \mathrm{kDa}, 100 \mathrm{kDa}$ $\sim 30 \mathrm{kDa}, 30 \mathrm{kDa} \sim 10 \mathrm{kDa}, 10 \mathrm{kDa} \sim 3 \mathrm{kDa},<3 \mathrm{kDa}$. The five water samples were tested for TOC, UV254 and UV260, respectively, and the three-dimensional fluorescence was used to analyze the types of organic compounds, then the microbiological risks were discussed. 


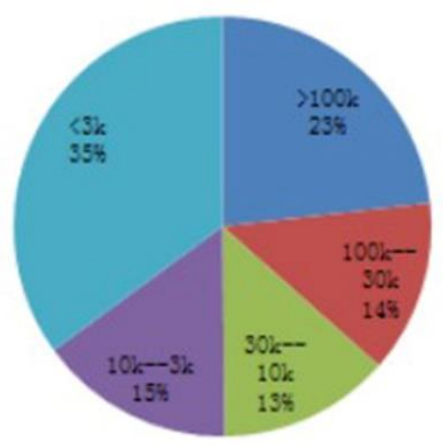

Figure 5a. Molecular weight classification results of DOC for reclaimed water

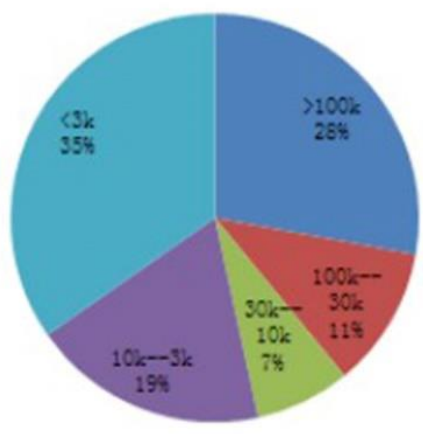

Figure 5b. Molecular weight classification results of UV254 for reclaimed water

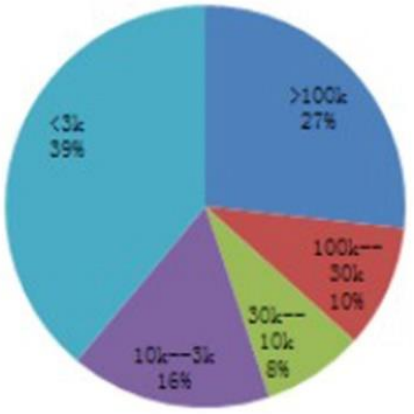

Figure 5c. Molecular weight classification results of UV260 for reclaimed water

Figure 5. Molecular weight classification for reclaimed water

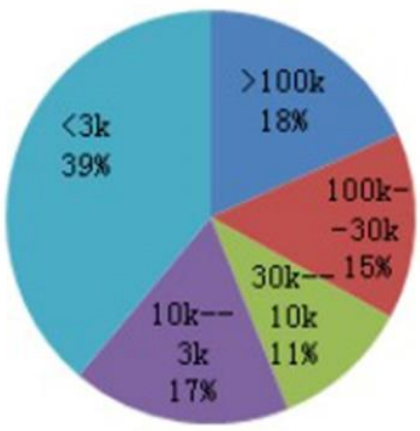

Figure 6a. Molecular weight classification results of DOC for circulating water

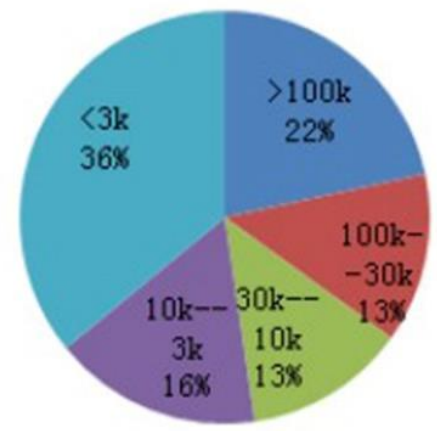

Figure 6b. Molecular weight classification results of UV254 for circulating water

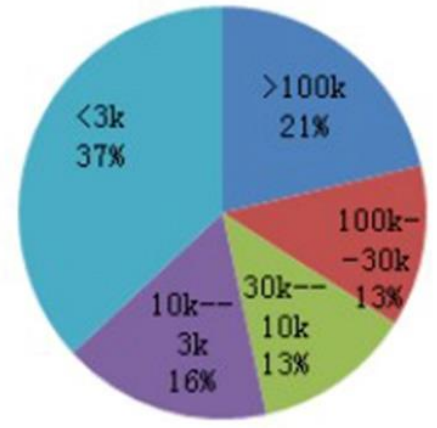

Figure 6c. Molecular weight classification results of UV260 for circulating water

Figure 6. Molecular weight classification for circulating water

As shown in Figure 5 and Figure 6, among the five samples of water samples obtained after the classification of reclaimed water, the DOC content of water samples with a molecular weight of less than $3 \mathrm{k}$ reached the highest value of $1.259 \mathrm{mg} / \mathrm{L}$, accounting for $35 \%$ of the total DOC. Followed by those with a molecular weight of more than 100k, the DOC content was $0.834 \mathrm{mg} / \mathrm{L}$, accounting for 23 $\%$ of the total DOC. The DOC contents of water samples with other molecular weight levels were relatively close, accounting for about $15 \%$ of the total DOC. Among the circulating cooling water, the content of DOC with molecular weight less than $3 \mathrm{k}$ was the highest, reaching $3.382 \mathrm{mg} / \mathrm{L}$, accounting for $39 \%$ of total DOC and was 2.69 times of the reclaimed water, the organic matter of small molecular weight was more able to be absorbed by microorganisms and utilization, so the microorganisms risk in circulating cooling water was more serious; followed by DOC of more than 100k molecular weight, and the content was $1.592 \mathrm{mg} / \mathrm{L}$, accounting for $18 \%$, Which was 1.91 times of reclaimed water, the organic matter with a molecular weight of more than $100 \mathrm{k}$ was mostly nondegradable organics originally present in sewage. The DOC content of water samples with other molecular weight levels was relatively close. The proportion of DOC with molecular weights between $100-30 \mathrm{k}$ and 10-30 k increases slightly while the DOC between 30-10k decreases slightly. In addition, the UV254 and UV260 values of different molecular weights have a good correlation with the DOC values of water samples. 

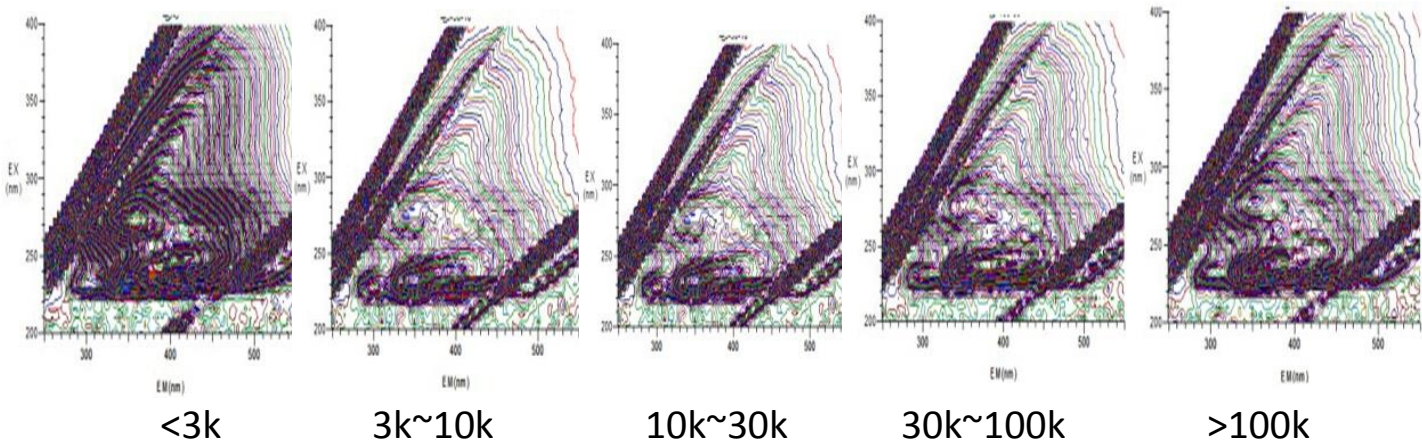

Figure 7. Analysis of three-dimensional fluorescence in reclaimed water
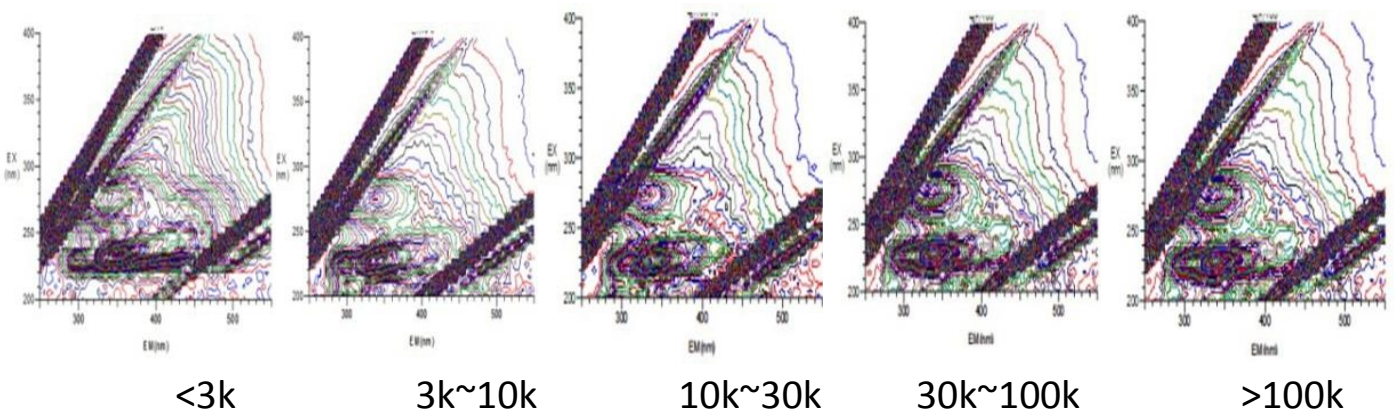

Figure 8. Analysis of three-dimensional fluorescence in circulating water

Table 4. The Identity of the Fluorescence Location for Common Organic in Water

\begin{tabular}{cccc}
\hline sign & species & excitation wavelength (Ex) & emission wavelength (Em) \\
\hline A & UV humus & $237 \sim 260$ & $400 \sim 500$ \\
\hline C & humus & $300 \sim 370$ & $400 \sim 500$ \\
\hline C1 & humic acid & $320 \sim 340$ & $410 \sim 430$ \\
\hline C2 & humic acid & $370 \sim 390$ & $460 \sim 480$ \\
\hline D & Soil fulvic acid & 390 & 509 \\
\hline E & Soil fulvic acid & 455 & 521 \\
\hline T1 & tryptophan & 275 & 340 \\
\hline T2 & tryptophan & $225 \sim 235$ & $340 \sim 381$ \\
\hline B1 & tyrosine & 275 & 310 \\
\hline B2 & tyrosine & $225 \sim 235$ & $309 \sim 321$ \\
\hline M & marine humus & $290 \sim 310$ & $370 \sim 410$ \\
\hline N & Relevant phytoplankton productivity & 280 & 370 \\
\hline
\end{tabular}

According to the analysis in Figure 7, Figure 8 and Table 4, the material types in reclaimed water and recirculating cooling water are the same, but the contents of $\mathrm{T} 1$ tryptophan, $\mathrm{B} 2$ tyrosine, $\mathrm{T} 1$ tryptophan and A humus in circulating cooling water were significantly higher than that of reclaimed water, especially in the water samples with a molecular weight of less than $3 \mathrm{k}$. Table 4 shows that in circulating cooling water, the protein content of small molecular weight organics was the highest, providing sufficient nitrogen source for the growth of microorganisms and further increases the microbial risk.

Comparison of suspended and immobilized microorganisms. 

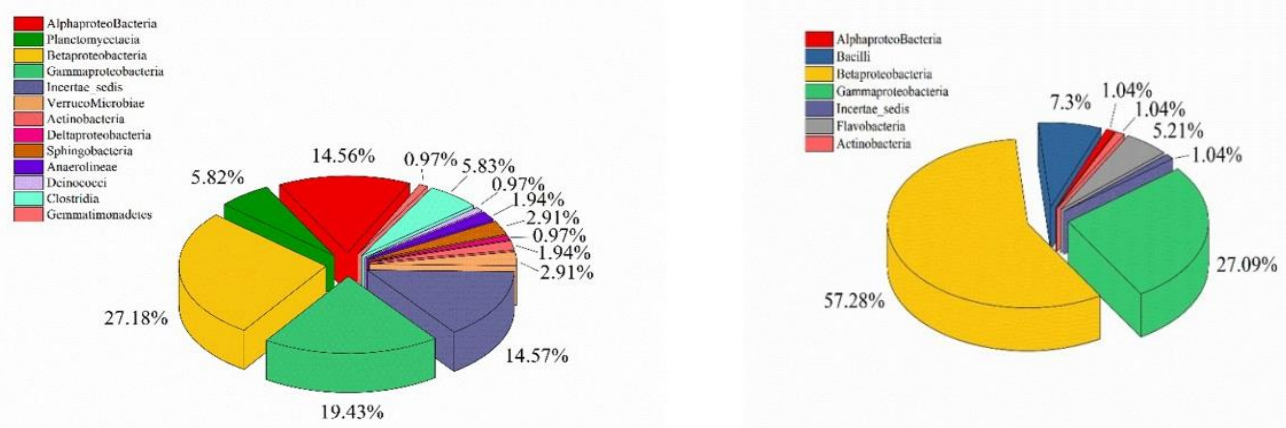

Figure 9. Microbial population structure at the level of class

Figure 9 showed that there were 7 kinds of suspended bacteria and 13 kinds of immobilized microorganisms in circulating cooling water. Only Actinobacteria, Alphaproteobacteria, Betaproteobacteria, Gammaproteobacteria were the common class.

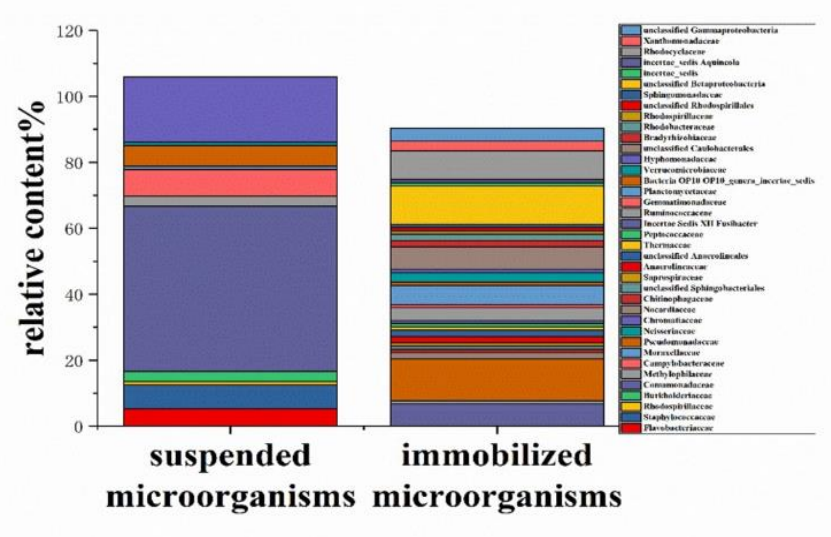

Figure 10. Microbial population structure at the level of family

At the level of family, there were 13 kinds of suspended microorganisms and 36 kinds of immobilized microorganisms. There was a big difference of the color's type and the corresponding bar's height between the two samples. The bacterial species of immobilized microorganisms were richer in circulating cooling water.

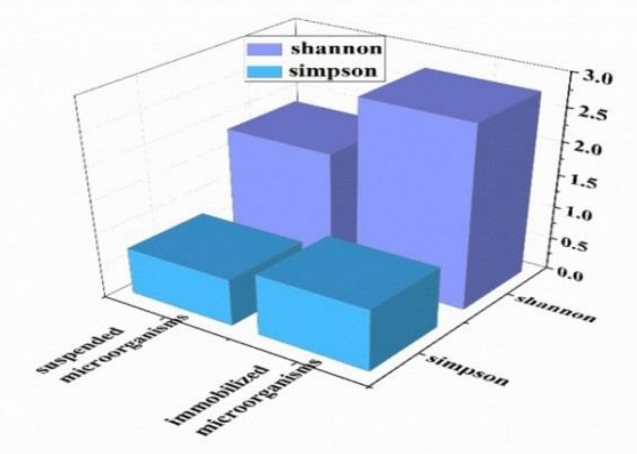

Figure 11. Compasion of shanoon and simpson index 
Compared with suspended microorganisms, the Shanoon and Simpson index of immobilized microorganisms increased 1.50 times and $30.43 \%$ respectively. The immobilized microorganisms in circulating cooling water had a higher diversity and the species were more evenly distributed. The reason is the complex micro-ecological environment in biofilm, the ability of microorganisms to resist environmental change of the microorganisms was strong in the complex micro-ecological environment and it was more suitable for microorganisms to survive and reproduce.

Table 5. The Dominant Suspended and Immobilized Microorganisms in Circulating Water

\begin{tabular}{|c|c|c|}
\hline \multirow{2}{*}{ number } & \multicolumn{2}{|c|}{ circulating cooling water without water treatment agents } \\
\hline & suspended microorganisms & immobilized microorganisms \\
\hline 1 & $\begin{array}{l}\text { Proteobacteria } \\
\text { Betaproteobacteria } \\
\text { Burkholderiales } \\
\text { Comamonadaceae } \\
47.9 \%\end{array}$ & $\begin{array}{l}\text { Proteobacteria } \\
\text { Gammaproteobacteria } \\
\text { Pseudomonadaceae } \\
\text { Pseudomonadaceae } \\
12.63 \%\end{array}$ \\
\hline 2 & $\begin{array}{l}\text { Proteobacteria } \\
\text { Gammaproteobacteria } \\
\text { Chromatiales } \\
\text { Chromatiaceae } \\
\text { Rheinheimera } \\
18.8 \%\end{array}$ & $\begin{array}{l}\text { Proteobacteria } \\
\text { Betaproteobacteria } \\
\text { Methylophilales } \\
\text { Methylophilaceae } \\
6.8 \%\end{array}$ \\
\hline 3 & $\begin{array}{l}\text { Firmicutes } \\
\text { Bacilli } \\
\text { Bacillales } \\
\text { Staphylococcaceae } \\
\text { Staphylococcus } \\
7.3 \%\end{array}$ & $\begin{array}{l}\text { Proteobacteria } \\
\text { Gammaproteobacteria } \\
\text { Pseudomonadales } \\
\text { Pseudomonadaceae } \\
\text { Pseudomonas } \\
5.8 \%\end{array}$ \\
\hline
\end{tabular}

It can be seen from Table 5 that the highest abundance of suspended microorganisms in circulating cooling water was Comamonadaceae from Betaproteobacteria, which accounted for $47.9 \%$, while was Pseudomonadaceae from Gammaproteobacteria accounting for $12.63 \%$ of immobilized microorganisms.

Comparison of circulating cooling water with or without agents.

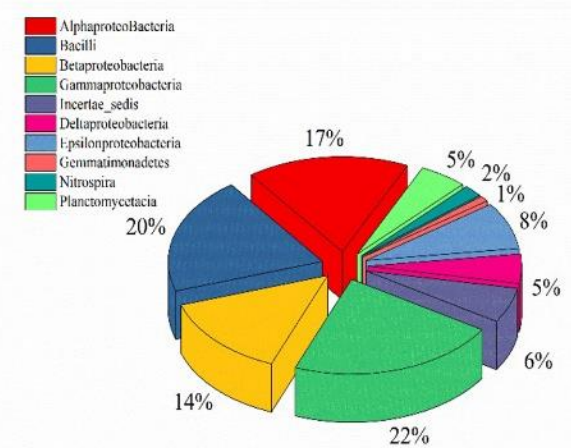

Without water treatment agents

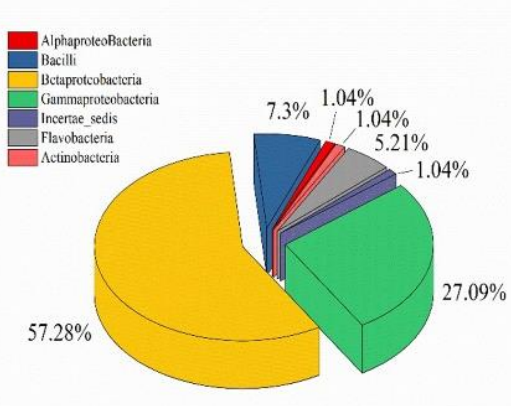

With water treatment agents

Figure 12. Microbial population structure at the level of class

Only Bacilli, Alphaproteobacteria, Betaproteobacteria, Gammaproteobacteria were the common class, and the largest number of class without water treatment agents was Betaproteobacteria, while was Gammaproteobacteria with water treatment agents. 


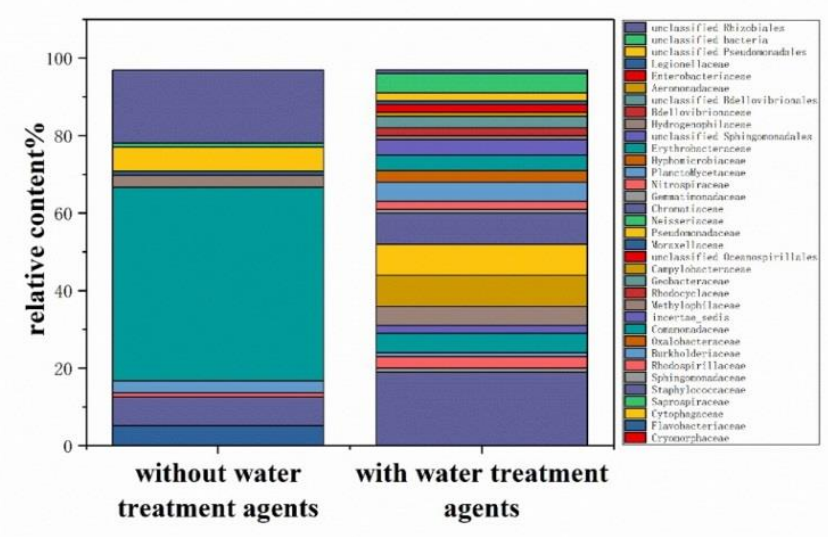

Figure 13. Microbial population structure at the level of family

At the level of family, there were 13 kinds of microorganisms without water treatment agents while 26 kinds with water treatment agents. There was a big difference of the color's type and the corresponding bar's height between the two samples. The bacterial species was richer in circulating cooling water with water treatment agents.

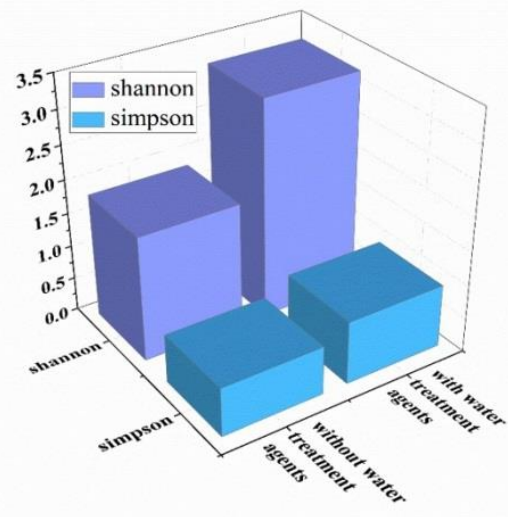

Figure 14. Compasion of shanoon and simpson index

Compared with circulating cooling water without water treatment agents, the Shanoon and Simpson index increased 1.74 times and $29.60 \%$ respectively with water treatment agents. The circulating cooling water with water treatment agents had a higher diversity and the species were more evenly distributed.

Table 6. The dominant microorganisms in circulating water with or without agents

\begin{tabular}{|c|c|c|}
\hline number & $\begin{array}{l}\text { circulating cooling water without } \\
\text { water treatment agents }\end{array}$ & $\begin{array}{l}\text { circulating cooling water with } \\
\text { water treatment agents }\end{array}$ \\
\hline \multirow{5}{*}{1} & Proteobacteria & Firmicutes \\
\hline & Betaproteobacteria & Bacilli \\
\hline & Burkholderiales & Bacillales \\
\hline & Comamonadaceae & Staphylococcaceae \\
\hline & $47.9 \%$ & $19 \%$ \\
\hline \multirow{5}{*}{2} & Proteobacteria & Proteobacteria \\
\hline & Gammaproteobacteria & Gammaproteobacteria \\
\hline & Chromatiales & Chromatiales \\
\hline & Chromatiaceae & Chromatiaceae \\
\hline & Rheinheimera & Rheinheimera \\
\hline
\end{tabular}




\begin{tabular}{lll}
\hline & Firmicutes & Proteobacteria \\
Bacilli & EpsilonproteoBacteria \\
Bacillales & Campylobacterales \\
Staphylococcaceae & Campylobacteraceae Sulfurospirillum \\
Staphylococcus & $6 \%$ \\
\hline $7.3 \%$ & \\
\hline
\end{tabular}

It can be seen from Table 6 that after adding water treatment agents, the highest abundance of microorganisms become Staphylococcaceae from Firmicutes accounting for $19 \%$, which was in a big difference with the circulating water without water treatment agents. So, water treatment agents had a great influence on the microbial community structure.

In accordance with the dosing scheme of power plant circulating water and the corresponding indicators was detected.

Table 7. Dosing Scheme of Power Plant Circulating Water

\begin{tabular}{lllll}
\hline $\begin{array}{l}\text { Pharmacy } \\
\text { name }\end{array}$ & $\begin{array}{l}\text { chlorine } \\
\text { compound }\end{array}$ & $\begin{array}{l}\text { BC-806 Carbon steel } \\
\text { corrosion inhibitor }\end{array}$ & $\begin{array}{l}\text { BC-802BS Copper } \\
\text { corrosion inhibitor }\end{array}$ & $\begin{array}{l}\text { BC-817BS Scale and } \\
\text { corrosion inhibitor }\end{array}$ \\
\hline Density & & $1.2 \pm 0.005 \%$ & $\geq 15 \%$ & $1.15 \mathrm{~g} / \mathrm{cm}^{3}$ \\
\hline Dosage & $150 \mathrm{mg} / \mathrm{L}$ & $6 \mathrm{mg} / \mathrm{L}$ & $6 \mathrm{mg} / \mathrm{L}$ & $8 \mathrm{mg} / \mathrm{L}$ \\
\hline
\end{tabular}

Table 8. Comparative Results of Water Quality

\begin{tabular}{|c|c|c|c|c|c|}
\hline Index & Unit & $\begin{array}{l}\text { Circulating cooling } \\
\text { water }\end{array}$ & $\begin{array}{l}\text { With chlorine } \\
\text { compound }\end{array}$ & With corrosion inhibitor & With the two agents \\
\hline TOC & $\mathrm{mg} / \mathrm{L}$ & 13.82 & 39.45 & 26.48 & 44.34 \\
\hline $\mathrm{TP}$ & $\mathrm{mg} / \mathrm{L}$ & 0.697 & 1.540 & 21.556 & 22.944 \\
\hline Soluble TP & $\mathrm{mg} / \mathrm{L}$ & 0.490 & 1.298 & 21.803 & 21.247 \\
\hline $\mathrm{TN}$ & $\mathrm{mg} / \mathrm{L}$ & 36.726 & 34.838 & 36.624 & 34.550 \\
\hline Ammonia & $\mathrm{mg} / \mathrm{L}$ & 1.278 & 0.001 & 1.098 & 0.156 \\
\hline Nitrate nitrogen & $\mathrm{mg} / \mathrm{L}$ & 16.199 & 15.152 & 18.452 & 18.442 \\
\hline Nitrite nitrogen & $\mathrm{mg} / \mathrm{L}$ & 0.864 & 0.021 & 1.184 & 0.006 \\
\hline $\mathrm{SO}_{4}^{2-}$ & $\mathrm{mg} / \mathrm{L}$ & 175.873 & 143.8 & 326 & 268.273 \\
\hline$\overline{\mathrm{Cl}^{-}}$ & $\mathrm{mg} / \mathrm{L}$ & 369.353 & 533.026 & 471.981 & 514.663 \\
\hline
\end{tabular}

The test result of water quality showed that after adding water treatment agents, there was almost no change of the TN content, while TOC and TP increased a lot. After adding chlorine compound, the TOC and TP increased 2.85 times and 2.21 times, respectively. When adding corrosion inhibitor, the TOC and TP increased 1.92 times and 30.93 times, respectively. When the two agents were both added, the TOC and TP increased 3.21 times and 32.92 times, respectively. Therefore, the increase of TOC and TP content in circulating cooling water was the main reason for microbial growth. The common phosphorus corrosion inhibitor will lead to the increase of microbial risk at the time of easing metal corrosion and fouling.

Other nutrients such as the use of inorganic fertilizers are also known to affect microbial diversity [17]. Previous research suggests that microbial diversity generally and the diversity of highly beneficial arbuscular mycorrhizal fungi decline with the application of nitrogen $(\mathrm{N})$, phosphorus $(\mathrm{P})$ 
and potassium $(\mathrm{K})$ [18-19]. Li reported that the adding of charcoal to soil can change the content of available phosphorus, available calcium and organic carbon, thus affecting the microbial population structure [20].

\subsection{Potential Corrosion Damage}

Undoubtedly, the classification of corrosive microorganisms was of great significance for us to study the potential damage to metal. The types and proportions of sticky mud bacteria and corrosive bacteria were shown in Table 9.

Table 9. Information of sticky mud bacteria and corrosive bacteria

\begin{tabular}{|c|c|c|c|c|c|c|}
\hline $\begin{array}{c}\begin{array}{c}\text { Microbial } \\
\text { species }\end{array} \\
\end{array}$ & Harm & Bacteria & $\mathbf{a}$ & b & c & d \\
\hline \multirow{6}{*}{$\begin{array}{l}\text { Sticky mud } \\
\text { bacteria }\end{array}$} & \multirow{6}{*}{$\begin{array}{l}\text { Produce sticky secretions and } \\
\text { the secretions cause the metal } \\
\text { surface to form a strong } \\
\text { microbial scale, which will } \\
\text { block the pipeline and hinder } \\
\text { the role of water treatment } \\
\text { agents, resulting in under-scale } \\
\text { corrosion }\end{array}$} & Flavobacterium & $2.06 \%$ & $5.21 \%$ & & \\
\hline & & Staphylococcus & $5.16 \%$ & $7.30 \%$ & $19 \%$ & \\
\hline & & Acinetbacter & $1.03 \%$ & $1.04 \%$ & & \\
\hline & & Pseudomonas & $6.19 \%$ & $1.04 \%$ & $1 \%$ & $5.83 \%$ \\
\hline & & Aeromonas & & & $1 \%$ & \\
\hline & & The total ratio & $14.44 \%$ & $14.59 \%$ & $21 \%$ & $5.83 \%$ \\
\hline \multirow{7}{*}{$\begin{array}{l}\text { Corrosive } \\
\text { bacteria }\end{array}$} & \multirow{7}{*}{$\begin{array}{l}\text { Causing metal corrosion } \\
\text { directly }\end{array}$} & Acidovorax & $4.13 \%$ & & & \\
\hline & & Sulfurospirillum & $1.03 \%$ & & $6 \%$ & \\
\hline & & Rhodobacter & & & & $0.97 \%$ \\
\hline & & Sphingosinicella & & & & $0.97 \%$ \\
\hline & & Nitrospira & & & $2 \%$ & \\
\hline & & Thiobacillus & & & $1 \%$ & \\
\hline & & The total ratio & $5.16 \%$ & & $9 \%$ & $1.94 \%$ \\
\hline
\end{tabular}

a) Municipal reclaimed water. b) Suspended microorganisms in Circulating cooling water without water treatment agents. c) Suspended microorganisms in Circulating cooling water with water treatment agents. d) Immobilized microorganisms in circulating cooling water without water treatment agents.

It can be seen from Table 9 that in reclaimed water, the sticky mud bacteria and corrosive bacteria was respectively 14.44 and $5.16 \%$. After entering cooling water, the sticky mud bacteria increased a little which was $14.59 \%$. However, no corrosive bacteria were found. After adding agents, the ratio of both sticky mud bacteria and corrosive bacteria increased a lot, which was 21 and 9\%, respectively. The immobilized sticky mud bacteria and corrosive bacteria was 5.83 and $1.94 \%$, respectively. The common phosphorus corrosion inhibitor will lead to the increase of microbial risk at the time of easing metal corrosion and fouling. It is a fundamental way to control the growth of microorganisms by adjusting the addition of corrosion inhibitors and scale inhibitors. In addition, it can be seen from previous study that the growth of heterotrophic bacteria in the reclaimed water distribution system mainly depended on the residual chlorine concentration, and it is recommended to equip processes to remove biodegradable organic matter in water reclamation plants to improve biological stability [2021].

\section{Conculsions}

At the level of family, there were 17 kinds of suspended microorganisms in municipal reclaimed water, after entering the circulating cooling water system, 13 kinds of suspended microorganisms and 
36 kinds of immobilized microorganisms were detected, the dominant strain were both from Betaproteobacteria. After adding chemical agents, suspended microorganisms increased to 26 kinds, and the dominant strain become Staphylococcus from Firmicutes.

The Shanoon index in municipal reclaimed water, suspended and immobilized microorganisms in circulating cooling water system without water treatment agents and circulating cooling water with water treatment agents were 2.66, 1.85, 2.77, and 3.22, respectively. The Simpson index in the above four samples were $0.89,0.72,0.93$, and 0.94 , respectively. The suspended microorganisms in circulating cooling water without water treatment agents had the lowest diversity and the worst distribution uniformity. The immobilized microorganisms in circulating cooling water agents had the highest diversity and the species were evenly distributed.

This paper studies the population structure and dominant species of microorganisms in water when reclaimed water is used for recirculating cooling water supply. It was found that when chemical agents such as scale inhibitors and corrosion inhibitors were added to the reclaimed water, the population structure and biodiversity of the microorganisms in the water would change. It can be seen that in the process of reclaimed water reuse, microorganisms in the water are easily interfered by external factors, thereby exhibiting different biodiversity, which is more difficult to control the corrosion of microorganisms in the reclaimed water. Therefore, in the future, it is necessary to explore the diversity of microorganisms in water for the actual recycling process, so as to more accurately explore the mechanism of microbial corrosion.

Acknowledgements: This research was supported by National Natural Science Fundation of China (51578035), the Fundamental Research Funds for Beijing Universities (X18257, X18256). We also thank the support of Jingneng power plant for collecting water samples and carrying out the experiment.

\section{References}

1.JIN, J., WU, G., GUAN, Y., Effect of bacterial communities on the formation of cast iron corrosion tubercles in reclaimed water. Water. Res., 71(3), 2015, 207-218.

2.RAY, R. I., LEE, J. S., LITTLE, B. J., The anatomy of tubercles: A corrosion study in a fresh water estuary. Mater. Corr., 61(12), 2010, 993-999.

3.WANG, H., HU, C., HU, X., Effects of disinfectant and biofilm on the corrosion of cast iron pipes in a reclaimed water distribution system. Water. Res., 46(4), 2012, 1070-1078.

4.CHEN, L., JIA, R. B., LI, L., Bacterial community of iron tubercles from a drinking water distribution system and its occurrence in stagnant tap water. Environ. Sci. Proc. Imp., 15(7), 2013, 1332-1340.

5.ZHU, Y., WANG, H., LI, X., Characterization of biofilm and corrosion of cast iron pipes in drinking water distribution system with UV/Cl2 disinfection. Water. Res., 60(9), 2014, 174-181.

6YANG, F., SHI, B., BAI, Y., Effect of sulfate on the transformation of corrosion scale composition and bacterial community in cast iron water distribution pipes. Water. Res., 59(8), 2014, 46-57.

7.SUN, H., SHI, B., BAI, Y., Bacterial community of biofilms developed under different water supply conditions in a distribution system. Sci. Total. Environ., 472(2), 2014, 99-107.

8.CHEN, L., JIA, R. B., LI, L., Bacterial community of iron tubercles from a drinking water distribution system and its occurrence in stagnant tap water. Environ. Sci. Proc. Imp., 15(7), 2013, 1332-1340.

9.BAYATZADEH, M. A., POURBAKHSH, S. A., HOMAYOUNIMEHR, A. R., Application of culture and polymerase chain reaction (PCR) methods for isolation and identification of Mycoplasma synoviae on broiler chicken farms. Arch. Razi Inst., 66(2), 2011, 87-94.

10.WANG, M., ZHAO, Y., LU, S. S., Characteristics of microbial community structure during isolation of electrical active bacteria. Huan. Jing. Ke. Xue., 35(10), 2014, 3940-3946.

11.VEZZULLI, L., STAGNARO, L., GRANDE, C., Comparative 16SrDNA gene-based microbiota 
profiles of the Pacific oyster (Crassostrea gigas) and the Mediterranean mussel (Mytilus galloprovincialis) from a shellfish farm (Ligurian Sea, Italy). Microb. Ecol., 75(2), 2018, 495-504.

12.FRENCH, K. E., TKACZ, A., TURNBULL, L. A., Conversion of grassland to arable decreases microbial diversity and alters community composition. Appl. Soil. Ecol., 110(2), 2017, 43-52.

13.WU, C., SHI, L., XUE, S., Effect of sulfur-iron modified biochar on the available cadmium and bacterial community structure in contaminated soils. Sci. Total. Environ., 647(1), 2019, 1158-1168.

14.THAYANUKUL,, P., KURISU, F., KASUGA, I., Evaluation of microbial regrowth potential by assimilable organic carbon in various reclaimed water and distribution systems. Water Res., 47(1), 2013, 225-232.

15.WANG, H., AN, X., ZHANG, Z., Effect of advanced treatment on ammonia nitrogen contained in secondary effluent from wastewater treatment plant. Fresenius. Environ. Bull., 27(4), 2018, 20432050.

16.GU, F., ZHANG, W., GUO, J., HALL, P., Exploring "Internet+ Recycling”: Mass balance and life cycle assessment of a waste management system associated with a mobile application. Sci. Total. Environ., 649, 2019, 172-185.

17.WANG, M., ZHANG, D., CHENG, Y., TAN, S. K., Assessing performance of porous pavements and bioretention cells for stormwater management in response to probable climatic changes. $J$. Environ. Manag.t, 243, 2019, 157-167.

18.LIU, Z., FENG, J., WANG, J., Resource-Constrained Innovation Method for Sustainability: Application of Morphological Analysis and TRIZ Inventive Principles. Sustainability, 12(3), 2020, 917.

19.ZHANG, Y., ZHANG, X., LI, M., LIU, Z., Research on heat transfer enhancement and flow characteristic of heat exchange surface in cosine style runner. Heat Mass Transfer, 55(11), 2019, 3117 3131 .

20.NNAEMEKA, A.N., Environmental pollution and associated health hazards to host communities (Case study: Niger delta region of Nigeria). Cent. Asian J. Environ. Sci. Technol. Innov., 1(1), 2020, 30-42.

21.JABEEN, S., MAHMOOD, Q., NAWAB, B., High economic impacts of poor water and sanitation in various communities in Pakistan (An environmental economic perspective). Cent. Asian J. Environ. Sci. Technol. Innov., 1(1), 2020, 53-60.

$\overline{\text { Manuscript received: } 17.03 .2020}$ 